German Journal of Research in Human Resource Management, 27(3)

Zeitschrift für Personalforschung, 27. Jahrgang, Heft 3, 2013 ZfP 27(3)

German Journal of Research in Human Resource Management, Volume 27, Issue 3

Special issue

Current issues in International HRM: Alternative forms of assignments, careers and talent management in a global context

edited by Marion Festing, Pawan S. Budhwar, Wayne Cascio, Peter J. Dowling, Hugh Scullion

Marion Festing, Pawan S. Budhwar, Wayne Cascio, Peter J. Dowling, Hugh Scullion

Current issues in International HRM: Alternative forms of assignments, careers and talent management in a global context

Frithjof Arp

Typologies: What types of foreign executives are appointed by local organisations and what types of organisations appoint them?

Iris Kollinger-Santer, Iris C. Fischlmayr

Work life balance up in the air - Does gender make a difference between female and male international business travelers?

Stefan Remhof, Marjaana Gunkel, Christopher Schlägel

Working in the "global village": The influence of cultural intelligence on the intention to work abroad

Marlene Walk, Heike Schinnenburg, Femida Handy

What do talents want? Work expectations in India, China, and Germany

Denise Ewerlin

The influence of global talent management on employer attractiveness: An experimental study

Editorial board of this special issue:

Prof. Dr. Maike Andresen, University of Bamberg, Germany

Prof. Dr. Joytsna Bathnagar, Management Development Institute, Gurgaon, India

Prof. Dr. Allen D. Engle, School of Business, Eastern Kentucky University, USA

Dr. Hosein Gharavi, La Trobe University, Australia

Dr. Sam Kovacevic, La Trobe University, Australia

Dr. Alma McCarthy, Cairnes School of Business and Economics, NUI Galway, Ireland

Dr. Anthony McDonnell, School of Management, University of South Australia, Australia Prof. Dr. Jaap Paauwe, Tilburg University, The Netherlands

Prof. Dr. Markus Pudelko, University of Tuebingen, Germany

Prof. Dr. Yee Ng Kok Yee, Nanyang Technological University, Singapore 


\section{Frithjof Arp* \\ Typologies: What types of foreign executives are appointed by local organisations and what types of organisations appoint them?**}

Current issues in international human resource management include global careers that differ from traditional expatriate assignments. A number of foreign executives have in recent years been appointed to positions in the headquarter operations of culturally distant organisations. These appointments of foreign executives in local organisations (FELOs) can be viewed as a specific form of self-initiated expatriation (SIE), with several distinct types of FELOs found in fieldwork studies. This article offers typologies of the individuals and organisations involved in the FELO phenomenon. These typologies elucidate that FELO appointments do not necessarily indicate a geocentric hiring approach, and assist in identifying which FELO workplaces produce successful outcomes as well as those which are likely to fail. The applicability to other country contexts, implications for theory on diversity in management teams, and key criteria for FELO hiring practices are discussed.

\section{Typologien: Welcher Typus ausländischer Führungskräfte wird von lokalen Unternehmen verpflichtet, und welcher Typus lokaler Unternehmen verpflichtet sie?}

$\mathrm{Zu}$ aktuellen Themen der internationalen Personalforschung zählen globale Karrieren, die sich deutlich von traditionellen Auslandsentsendungen unterscheiden. In den letzten Jahren ist eine Anzahl ausländischer Führungskräfte in die Unternehmenszentralen kulturell ferner Organisationen verpflichtet worden. Diese foreign executives in local organisations (FELOs) können als spezifische Form selbstinitiierter Expatriierung (SIE) betrachtet werden, wobei in Feldstudien dezidiert unterschiedliche Typen von FELOs gefunden wurden. Dieser Artikel legt Typologien der im FELO-Phänomen involvierten Personen und Organisationen vor. Sie zeigen auf, dass die Verpflichtung ausländischer Führungskräfte nicht unbedingt auf geozentrische Personalpraktiken hinweist und helfen, erfolgreiche sowie zum Scheitern neigende Arbeitsverhältnisse zu identifizieren. Die Anwendbarkeit auf unterschiedliche Länderkontexte, Implikationen für Theorien über kulturelle Vielfalt in Managementteams und die wichtigsten Kriterien der FELO Einstellungspraxis werden erörtert.

Key words: foreign executives, expatriates, self-initiated expatriation, cultural distance, typologies (JEL: M12, M14, M16, M51, Z10)

* Dr. Frithjof Arp, Department of Management, Faculty of Business \& Economics, Monash University, Melbourne, Australia.

E-mail: frithjof.arp@monash.edu, FELOresearch@gmail.com, www.FELOresearch.info.

** Anonymous reviewers have contributed to this article through constructive criticism. They encouraged a clearer distinction of the FELO phenomenon from other concepts in the literature, extended discussion and implication sections, and further clarification of some parts of the individual and organisational typologies. Their contribution is much appreciated.

Article received: December 28, 2012

Revised version accepted after double blind review: July 20, 2013. 


\section{Introduction}

A number of foreign executives have in recent years been appointed to positions in the headquarter operations of culturally distant organisations. International executive search consultants have been retained, for instance, to find 'Western' executives for Korean, Japanese and Chinese companies (see e.g. The Korn/Ferry Institute, 2009). While these foreign executives in local organisations (FELOs) can probably best be viewed as a specific form of self-initiated expatriation (SIE), their workplaces differ significantly from typical expatriate assignments (Arp, Hutchings, \& Smith, 2011, forthcoming 2013).

For example, FELO workplaces are different from the subsidiaries of foreign multinationals in that they are often share-market listed and can be among 'national icons'. The host-country nationals (HCNs) that FELOs supervise, and HCN superiors that they report to, ascribe a 'local' national identity to these organisations. While the superiors of expatriates often know little about distant subsidiary operations, FELOs report to local chairpersons, family-owners or dominant shareholders that are well informed about, and often have significant influence on, operational decisions. While traditional expatriates in the local subsidiaries of multinationals pursue foreign objectives, FELOs have to demonstrate that they serve local interests. These and other points of distinction are prominently mentioned by participants of in-depth interview studies (e.g. Arp, forthcoming 2013; Arp et al., 2011), highlighting that FELOs as well as their local peers perceive these workplaces to be quite different from other forms of expatriation. In addition, research with these two groups of executives illustrates that the reasons why foreign executives are initially appointed in spite of significant cultural distance, what they contribute to the local organisations that they work for, why some of them remain in their positions, and why these positions are not filled with local executives (Arp, forthcoming 2013), have little to do with the reasons for traditional expatriate assignments (i.e. trust; allegiance; control of foreign subsidiaries, see e.g. Harzing, 2001a; Harzing, 2001b). Indeed, case studies illustrate that foreign executives are sometimes specifically hired to compete against expatriates representing foreign multinationals in the domestic markets of their local employers (Arp, 2012). The same case studies demonstrate that FELOs work in very different organisational contexts from, and without the perceived 'safety net' of, other expatriates. Fieldwork for these studies also found several distinct types of FELOs, thus highlighting the need to develop typologies. This is a gap that the present study aims to address.

\section{Theoretical framework}

The international human resource management (IHRM) literature categorises as SIE those international workplaces where individuals have not been assigned to their hostcountry by an employer. The originators of the SIE construct had noted that "every year thousands of young people head overseas for a prolonged period of travel, work, and tourism" (Inkson, Arthur, Pringle, \& Barry, 1997, p. 358), and SIE research has been at a crossroad of management, tourism, and labour migration ever since. Indeed, some recent reviews "seek clarification of the SIE construct", noting that the SIE literature is growing "but seems to be developing without a clear basis" (Doherty, 
Richardson, \& Thorn, 2013, p. 108). An increasing variety of studies not directly concerned with managerial level issues are placed under the SIE construct, including contract workers from neighbouring countries in Singapore (Lee, 2005), nurses in Saudi Arabia (Bozionelos, 2009), and studies of academics teaching abroad (Froese, 2012; Richardson \& Mallon, 2005; Selmer \& Lauring, 2010, 2011, 2012). Many SIEs researched to date work in foreign subsidiaries of established multinational firms rather than local organisations (see e.g. sample in Vance, 2005) and some SIEs may decide to settle permanently in their host countries and thus become migrants (Suutari \& Brewster, 2000). Further, most SIEs do not work in host-countries of significant cultural distance (Inkson et al., 1997; Inkson \& Myers, 2003; Lee, 2005; Myers \& Pringle, 2005; Suutari \& Brewster, 2000), and the few that do work for local organisations do not hold managerial positions (see analysis of SIE studies and samples in Arp et al., forthcoming 2013).

The present study differs from the extant literature on SIE mentioned above. Avoiding the "broad and necessarily subjective interpretation of what SIE encompasses" (Doherty et al., 2013, p. 97), research of the FELO phenomenon focuses on managerial, international and cross-cultural issues by investigating a specific group of (a) individuals at the managerial level, (b) workplaces in local organisations rather than subsidiaries of foreign multinationals, and (c) workplace relationships involving significant cultural distance. The importance of investigating and categorising these exceptional cross-cultural workplaces lies in the need to understand which types of individuals, organisations and hiring strategies are involved. Typologies will assist in identifying which FELO workplaces produce successful outcomes and those which are likely to fail.

FELOs are exposed to heightened levels of scrutiny (Arp et al., 2011, forthcoming 2013). They have to bridge cultural distance in exceptional circumstances as they hold managerial positions in the headquarters of organisations to which hostcountry nationals (HCNs) they supervise, and shareholders they report to, ascribe a 'local' national identity. Hymer (1960), Zaheer (2002) and Nachum (2006) note that organisations around the world have a local identity as they are perceived to be 'one of ours' in their home country. However, Zaheer (2002, p. 352) writes that "local does not necessarily mean domestic" as a local organisation can have international operations. Thus, the term 'local' connotes where organisations are founded and headquartered, and that FELO workplaces are not in foreign subsidiaries but in the headquarters. Despite Zaheer's (2002, p. 352) observation, scholarship more frequently takes an interest in the international operations of established multinationals than in local organisations' headquarters. The hiring of foreign executives into positions at headquarters of local organisations remains under researched, and the present study thus makes a clear point of difference.

\section{Difference to other concepts and research questions}

The acronym FELO was developed to avoid confusion with other concepts such as 'inpatriate'. The main proponents of inpatriation define it as "the relocation of foreign employees/managers to the parent country of the organization" (Harvey, Reiche, \& Moeller, 2011, p. 1, emphasis added). The relocation of existing employees differs from 
the appointment of FELOs as it occurs within a multinational organisation. In addition, the term 'inpatriate' has added a level of confusion surrounding the definition of an expatriate, as its proponents define HCNs as inpatriates. However, HCNs only become 'inpatriates' when they are transferred into the multinational's parent-country operations as expatriates, and it is questionable "whether the term 'inpatriate' adds enough value to justify its use" (Dowling, Festing, \& Engle, 2008, p. 4). The semantics and etymology of the term inpatriate are similarly confused. First, inpatriates are not in but out of their patria (Latin, "Fatherland"). Second, if the term was meant to be antonymic to expatriate, it would have to be impatriate (just as import is antonymic to export). In addition, inpatriation proponents predominantly focus on reassignments for the purpose of expansion of globalised MNOs into the country-of-origin of the inpatriate: "the emerging market that the organization is attempting to penetrate" (Harvey, Novicevic, \& Speier, 1999. p. 41). This is not the case for the different, rare and specific international FELO workplaces of interest here.

Fieldwork for in-depth interview studies (Arp, forthcoming 2013; Arp et al., 2011) found several distinct types of FELOs, of which two were illustrated in case studies (Arp, 2012). Questions from scholars and industry practitioners such as executive search consultants about the implications for practice from those studies emphasise the need for a more comprehensive individual and organisational typology. To fill this gap, the research questions addressed in the present article are: (RQ1) what types of foreign executives are appointed by local organisations? And: (RQ2) what types of local organisations appoint foreign executives? The article begins with a review of extant international workplace typologies, and discusses the extent to which they may help explain what type of individuals and organisations are involved in the FELO phenomenon. This review is followed by a description of the methods utilised in the research. The empirical part of this article then presents typologies that emerged from the data of 46 FELO workplaces in Malaysia, triangulated from in-depth interviews with foreign and local participants, and further validated through comparison with FELO cases in other countries. After discussing these typologies and their limitations, the article concludes with suggestions for further research.

\section{Literature review}

\section{Typologies of individuals in international workplaces}

The literature offers a large number of international workplace typologies (Björkman \& Stahl, 2006; Black \& Gregersen, 1992; Caligiuri \& Colakoglu, 2007; Harzing \& Ruysseveldt, 2004). However, these typologies are not entirely applicable to FELOs due to the difference of FELO workplaces to traditional expatriate assignments (Arp et al., 2011).

\section{Expatriates}

Black and Gregersen (1992), for example, distinguish 'dual allegiance'-expatriates from those with their 'hearts at home', others described as 'hired guns / free agents' and yet others that have 'gone native'. They consider 'dual allegiance'-expatriates the most desirable while describing 'hired guns' as internationally experienced specialists without much allegiance to either the local subsidiary or the distant corporate headquarters, 
committed only to their 'gun slinging' careers in various host-countries and the economic benefits of their 'expatriate package'. A sub-category of hired guns is described as 'plateaued-career free agents' without opportunities in their home country and little international experience or language skills, who take on international assignments to progress their careers and are "attracted by the sweet financial packages common to most overseas assignments" (Black \& Gregersen, 1992, p. 63). In turn, 'gone natives' are described as expatriates with long host-country experience, high levels of commitment to the subsidiary operations, strong identification with and attachment to their host-country's culture, language, values and business practices. Parallels of these descriptions to some FELOs are apparent from the findings in the present study, help in distinguishing between different types of FELOs, and are discussed below.

Other early typologies focus on the roles and tasks of expatriates. Hays (1974), for example, distinguishes structure reproducers, operatives, troubleshooters and chief executive officers. The latter drive all aspects of operations and strategy while operatives perform functional tasks in an existing operational structure, generally at a lower level supervisory position. Troubleshooters, in turn, are sent to a foreign subsidiary to analyse and solve operational problems while structure reproducers build or replicate structures in a foreign subsidiary such as financial reporting or production systems from another part of the MNO. This role- and task-focused typology is utilised in studies of selection and training (see e.g. Tung, 1981), helping to explain the contingency of these processes on the roles of expatriates and the tasks assigned (Tung, 1998). Roles for which FELOs are appointed and the tasks they are assigned constitute elements of the typologies presented in this study, too. While FELOs perform their roles at headquarters instead of foreign subsidiaries, and the driving of operations and strategy as well as the performing of functional tasks are standard elements of their workplaces, the distinct role of structure reproducer versus troubleshooter has been emphasised for FELOs (cf. Arp, forthcoming 2013). Hence, these roles constitute an important element of distinction in the FELO typologies presented below.

Further typologies take into account expatriate adjustment stages varying over time. Constructs of 'coping' with psychological and cross-cultural adjustment (see e.g. Searle \& Ward, 1990; Ward, 1996; Ward \& Kennedy, 1999) are combined to form variations of a 'U-curve' (Black \& Mendenhall, 1991). Shapiro, Ozanne and Saatcioglu (2008), for instance, suggest that a typology of expatriates may involve four distinct categories. These are the 'romantic sojourner' (a naïve and not very effective tourist type focused on the new experience), the 'foreign worker' (expatriates that have become disappointed with the local environment and realise that they are not on a permanent holiday), the 'skilled worker' (those that have accepted the host-country culture as it is and become valuable assets to their organisations), to the most effective type of 'partners' (expatriates that have developed a high level of cultural sensitivity, adjusted their own behaviour and influence the behaviour of their colleagues). The typology of FELOs presented here also takes into account adjustment stages over time, as data suggest that the tenure of appointments varies widely (Arp et al., 2011). In addition, the data analysis in this as well as other studies must note a potential survivorship bias in FELO samples as short-tenure appointments ('romantic sojourners') may be underrepresented. A typology of expatriates offered by Stahl et al. (2009) distin- 
guishes between developmental (or learning driven) and functional (demand driven) assignments as predictors of expatriate turnover intentions. While repatriation concerns (along with a lack of support from, and career advancement opportunities within, the parent-company) are reported to be a major source of frustration for both types of expatriates, those individuals who are most likely to do well in international positions (those on 'developmental or learning driven' assignments) are also the most likely to view their expatriation as a career stepping-stone to positions in other organisations. "Compared to functional assignees, developmental assignees [..] are also more optimistic about their career prospects with other possible employers [..] more inclined to leave their companies than functional assignees, presumably because they would have better career opportunities available outside their companies" (Stahl et al., 2009, p. 102; emphases added). In an earlier study of 494 expatriates assigned by German companies to 59 countries, Stahl, Miller and Tung (2002, p. 222; emphasis added) had found that "the vast majority of expatriates viewed their international assignment as an opportunity for skill development and future career advancement, even though it may not be with their current company". Yet this is nothing new, as most expatriates cite as their reasons for accepting international assignments not their desire to achieve project results or be good corporate citizens, but a sense of adventure, advancement of their personal development, and a wish to work in different cultures (Mendenhall \& Oddou, 1988). What may be new — as the present work on FELOs illustrates — is that the expatriates of multinationals today are more inclined to leave their companies to take up positions with local organisations (and thus become FELOs). A recent survey, for example, suggests that $38 \%$ of contemporary expatriates wish to remain in their host-country (GRTS, 2010). In view of these findings, it needs to be considered which types of expatriates become FELOs in order to avoid repatriation and reverse culture shock, and take up career advancement opportunities in local organisations instead - a question answered by the present study.

\section{Self-initiated expatriates and boundary-less careers}

The concept of a developmental type of expatriate in the Stahl et al. (2009) study resonates with the concepts of boundary-less careers (Arthur \& Rousseau, 1996; Bird, 1994), protean careers as described by Hall (1996), and the career-paths of learning driven individuals that are found in self-initiated expatriation (e.g. Inkson et al., 1997; Peltokorpi \& Froese, 2009; Suutari \& Brewster, 2000). Boundary-less careers are not limited to the crossing of physical national borders (that is, working in a foreign country), but include the crossing of metaphysical boundaries (that is, across socio-ethnoreligio-linguistic boundaries). The career capital of such boundary-less careers includes exposure to, and often significant involvement with, different thought, linguistic and paralinguistic expression, and cultural conceptualisations. Indeed, the crossing and bridging of metaphysical boundaries may extend to private relationships, such as marriage to culturally different local spouses (cf. Peltokorpi \& Froese, 2009). As case studies illustrate (Arp, 2012), a record of crossing and bridging such boundaries in their private life is an important element in the selection of suitable FELOs, and distinguish some types of FELOs from others. Hence, the typologies in the present study take into account private relationships and FELOs' boundary-spanning exposure under the 
headings of (a) being 'at home' in their host-country as well as (b) an ability to make use of their unique insider/outsider status.

The SIE concept exemplifies such notions of boundary-less and protean careers, and a typology of SIEs is provided by Suutari and Brewster (2000) from their study of Finnish engineering union members (a comparison of 147 SIEs and 301 organisational expatriates). Some SIEs in their sample work for local organisations, but primarily in nearby countries. Most work in European countries (69\%), and only a minority on distant shores (North America 10\%, Asia 13\%, and others 8\%). Hence, the defining criteria of the FELO phenomenon (work at executive level, in local organisations, and involving significant cultural distance) are largely absent in that study. The typology categorises (1) young opportunists travelling as tourists and working abroad, (2) job seekers primarily motivated by fear of unemployment at home, (3) middle-aged and international-minded officials in EU and UN organisations, (4) professionals that have decided to stay abroad longer or indefinitely, (5) professionals who repeatedly work abroad for different employers, and (6) trailing spouses of expatriates who have found work in the host-country. The authors note that category 4 includes respondents who have no plans to return to Finland, that there might be more such individuals in reality, and that "they might disappear altogether" (Suutari \& Brewster, 2000, p. 432) from longitudinal research samples of expatriates. Indeed, additional SIE studies highlight that many SIEs enter into "longer-term unification with friends, spouses, or relatives" and that "a significant proportion of SIEs in Japan is reported to have local partners" (Peltokorpi \& Froese, 2009, p. 1099 and p. 1104). This indicates that family- and private-life influences on the SIE phenomenon are probably underestimated, that the SIE construct is too loosely defined and that studies of SIEs, as mentioned earlier in the theoretical framework, sit at a crossroads between IHRM, sociology and migration-research (cf. Doherty et al., 2013). Importantly, the Suutari and Brewster (2000) typology also illustrates that the type of organisation providing the SIE workplace needs to be considered - a gap filled by the present study.

\section{Organisational typologies}

Based on work of Perlmutter (1969), the IHRM literature frequently categorises organisations as having ethno-, poly-, regio- or geo-centric hiring practices, and the present study's organisational typology partly utilises this broad categorisation. Caligiuri and Stroh (1995) establish empirically that non-ethnocentric management positively correlates with economic variables (return on capital, sales growth, return on equity, profit margin), and that ethnocentric management is significantly less successful. Nonethnocentric organisations benefit from an increased (global) talent pool, recruit the best managers for their needs, implement a genuinely strategic approach to their operations, and gain competitive advantage. Caligiuri and Stroh (1995) caution, however, that non-ethnocentric management is possible only within the economic, social, political and legal constraints of the country of operation. Pudelko and Harzing (2007), in turn, investigate HRM practices in the subsidiaries of American, Japanese and German companies and report that, increasingly, the deciding factor in appointments or promotions is merit and skill rather than ethnicity or nationality. However, such studies do not test HRM practices in the corporate headquarters, and American, Japanese or 
German companies may not necessarily have a geocentric HRM approach there. Indeed, studies in developed economies demonstrate that foreigners are rare in the boardrooms of the overwhelming majority of organisations (e.g. Caligiuri, Lazarova, \& Zehetbauer, 2004; Palmer \& Varner, 2007; Staples, 2007, 2008). Until empirically investigated at headquarters level in additional countries, it may be assumed that the reasons for FELO appointments in those countries are as mundane as in countries already investigated (Arp, forthcoming 2013).

Other typologies (e.g. Adler \& Gundersen, 2008) conceptualise a sequential progression of organisations from (1) a domestic phase where foreign activities are limited to the export of surpluses, via (2) a multi-domestic phase where activities include production and sales in several host countries, and expansion into new markets causes a great need for knowledge on target markets and cultures via (3) a multinational phase aiming for the standardisation of products and services, and foreign activities are used to achieve cost leadership, to a (4) global phase when worldwide sourcing is combined with adaptation to host-country needs. Prior to the present study it was conceivable that a similar sequential progression could be identified for local organisations appointing foreign executives from significantly different cultural backgrounds. However, although these distinct phases of organisational development were considered during fieldwork, the findings of the present study do not indicate these phases to be a clear part of the FELO workplace typology. Why FELO appointments may not be contingent on the internationalisation phase and market focus will be discussed below.

Further categorisations (e.g. Claessens, Djankov, \& Lang, 2000) distinguish large, small or medium-sized firms, stock market-listed vs. privately-held, or familycontrolled vs. government-linked companies (GLCs). Small- and medium-sized organisations comprise a large percentage of organisations globally, and some are even described as 'born global' because of their globally-minded founders (Weerawardena, Mort, Liesch, \& Knight, 2007). On the other hand, privately-held family companies are often brought down by an inability of family members to maintain, build on, and manage family empires once the founder is dead. For example, evidence from 93 of the largest family-run business groups in Thailand suggests that resources are funnelled out of family group firms when descendants take up key positions (Bertrand \& Schoar, 2006). GLCs suffer from concentrated ownership and control, too. Claessens, Djankov and Lang (2000) find high levels of state-control in 2,980 stock-market listed Asian organisations, and Nowland (2008) reports that separation of ownership and control in large Asian non-financial organisations is associated with increased organisational performance and market value. In addition, Fraser, Zhang and Derashid (2006) analyse stock-market listed organisations over a ten year period and find that organisations with political patronage (especially the larger ones in their sample) carry more debt than others. Indeed, "the direct participation by government officials in the control of a large part of the corporate sector opens up the possibility of wide-spread conflicts between public and private interests of some individuals, leading to crony capitalism" (Claessens et al., 2000, p. 109). In view of the positive role that outsiders may have in separating ownership and control, FELO typologies must take into account the size of organisations, private or government ownership, and level of political patronage. 
Zeitschrift für Personalforschung, 27(3), 167-194

DOI 10.1688/1862-0000_ZfP_2013_03_Arp 175

German Journal of Research in Human Resource Management, 27(3)

\section{Degree of internationalisation and the 'global mindset'}

Further typologies of organisations can be based on the degree of their internationalisation (DOI; see Sullivan, 1994), the mindset of their executive teams, and their levels of diversity and meritocracy. Various DOI measures have been developed, including quantitative measures (e.g., the number of foreign subsidiaries; foreign assets as percentage of total assets; foreign subsidiaries' sales as percentage of total sales; foreign employees as percentage of total employees; export sales as percentage of total sales), and attitudinal measures of the international experience of organisations' executive team (cumulative duration of executives' international assignments as percentage of the total years of work experience of the team; geographic dispersion of international operations across cultural zones) (Sullivan, 1994).

A number of studies have found links between such measures and organisational performance (e.g. Carpenter \& Fredrickson, 2001; Daily, Certo, \& Dalton, 2000). This has lead to the notion of a 'global mindset' - the cumulative cognitive abilities and outlook of an organisation's executive team (Levy, Beechler, Taylor, \& Boyacigiller, 2007). Teams with a global mindset are "more tolerant of other peoples and cultures, consider cultural diversity an asset, thrive on ambiguity, balance contradictory forces, and rethink boundaries" (Kedia \& Mukherji, 1999, p. 236). Tihanyi, Ellstrand, Daily and Dalton (2000), for example, find that top management teams (TMTs) with members who have international experience are associated with greater organisational levels of international diversification. Their findings further indicate that an education that provides significant opportunities to interact with students from other countries may facilitate the appreciation of other cultures, reducing some of the uncertainty associated with international business ventures. Accordingly, Mobley and Weldon (2006 p. 297) summarise that the "transformation to a global mindset comes not from home country leadership challenges but from experience in other cultures". Finally, Nummela, Saarenketo and Puumalainen (2004) report a significant positive correlation between the global mindset of executive teams and financial measures of organisational performance (including a larger percentage of revenues from foreign markets, and significantly more foreign business partners and customers). Therefore, to address RQ2 (What types of local organisations appoint foreign executives?), the organisational typology presented here considers the concepts of DOI and 'global mindset'. It takes into account the international work experience and education abroad of executive teams in local organisations. Large and small organisations, as well as their ownership structure and control are viewed in that context.

\section{Methods}

Data from in-depth interviews conducted in and around Kuala Lumpur from $27^{\text {th }}$ April to $23^{\text {rd }}$ September 2009 with 46 foreign executives and 25 local peers in organisations founded and headquartered in Malaysia are analysed. The two sample groups, representing individual and organisational perspectives, work for some of the largest companies listed on the Kuala Lumpur Stock Exchange, GLCs, as well as privately held small- and medium-sized enterprises (SMEs) in a wide range of manufacturing and service industries. 


\section{Data collection}

Interviews commenced with the collection of socio-biographical data including age, education, number of years in the organisation and host-country. The interviews then moved to broad, open-ended questions about the FELO positions and their role in the organisation. FELO interviewees were invited to elaborate on their careers, employers, how they came to the host-country and the position that they were working in, and what they did in that position. Equivalent questions about the foreign executives and the local organisations were asked of LOCALs, and probing questions were asked whenever appropriate to extract further explanations. Comparisons to other individuals and organisations were welcomed. As advocated by Minichiello et al. (2008), the wording and ordering of interview questions was flexible as the absence of specific information on the FELO phenomenon in the literature did not permit a rigidly structured interview instrument (cf. Crabtree \& Miller, 1999).

\section{Data analysis}

Interview recordings were transcribed, analyzed and coded into themes in NVIVO (version 8) software. Following the immersion / crystallisation approach described by Crabtree and Miller (1999), the coding and data analysis process started with free nodes that referred to differences between individuals and descriptions of local organisations. These free nodes were gradually sorted into a more hierarchical tree node structure (Richards, 2005). In addition, quasi-Boolean operations were employed on the coded data to construct intersections of nodes within NVIVO. The Boolean operations can then be interpreted as a typology category (for examples of node intersections and results, see Table 1). The data are presented here in the form of tables describing the categories of individuals and organisations and examples of verbatim quotes. Nodes in the verbatim quotes are given in bold italics to indicate the coding and sub-coding process.

It became apparent relatively early during the data collection that there are distinct categories of FELOs and local organisations. Verbatim comments, such as the following, clearly categorise two types of FELOs, using previous position and marriage to local spouses as distinguishing characteristics:

There is also that other group of expatriates [FELOs] who actually worked here [for MNOs], and a number of them hold very senior positions [..] Most of them are CEOs of the company. Now, when you reach that level, you're almost reaching retirement age, right? [..] They got used to the life here [..], and when they finish their contract, they work for local organisations. Now, this category of people has nothing to do with that [FELO] who is . . that married a Malaysian. (LOCAL\#); three coding nodes used for differentiation; two nodes used to describe these differentiations)

In addition, frequent interview comments describe distinct types of local organisations appointing FELOs, and being successful or less successful in leveraging these FELO workplaces for business success. These descriptions include references to 'ethnic' categorisations that often preoccupy Malaysians (ostensibly, Chinese family businesses vs. Malay or Indian companies), and the frequency of such comments is taken into account in the organisational typology. Wherever possible, the organisational typology takes into account extant typologies in the literature, such as stock market- 
German Journal of Research in Human Resource Management, 27(3)

listed vs. privately-held, staff diversity and DOI, or small to medium-sized (SMEs) vs. government-controlled (GLCs) organisations.

The robustness and reliability of the typologies is further strengthened by longitudinal data collected during fieldwork in Malaysia in November 2010 and April to June 2012, as well as comparisons with cases in other countries. The comparisons suggest the applicability of FELO typologies in other settings and similarities include the initial reasons for appointments, perceptions about the foreignness and unique insider/outsider status of FELOs, the increased ability of FELOs to manage change and address neglected issues, as well as their perceived or actual lack of bias as relative outsiders (Arp, forthcoming 2013).

\section{Findings}

\section{Typology of FELOs}

Five key characteristics of FELOs are noted most by interviewees, and are utilised to distinguish between typology categories. These are FELOs' (a) tenure in the local organisation (b) income level, (c) nationality of spouses, and (d) the level of host-country integration. A further element, (e) the ability of FELOs to make use of their unique insider/outsider status, is extracted from longer interview passages and anecdotes that require topical and analytical coding, rather than descriptive coding (see Richards, 2005). A non-numeric illustration of the relative likelihood of the five key characteristics for each type of FELO is shown in Figure 1.

Figure 1: Key typology characteristics
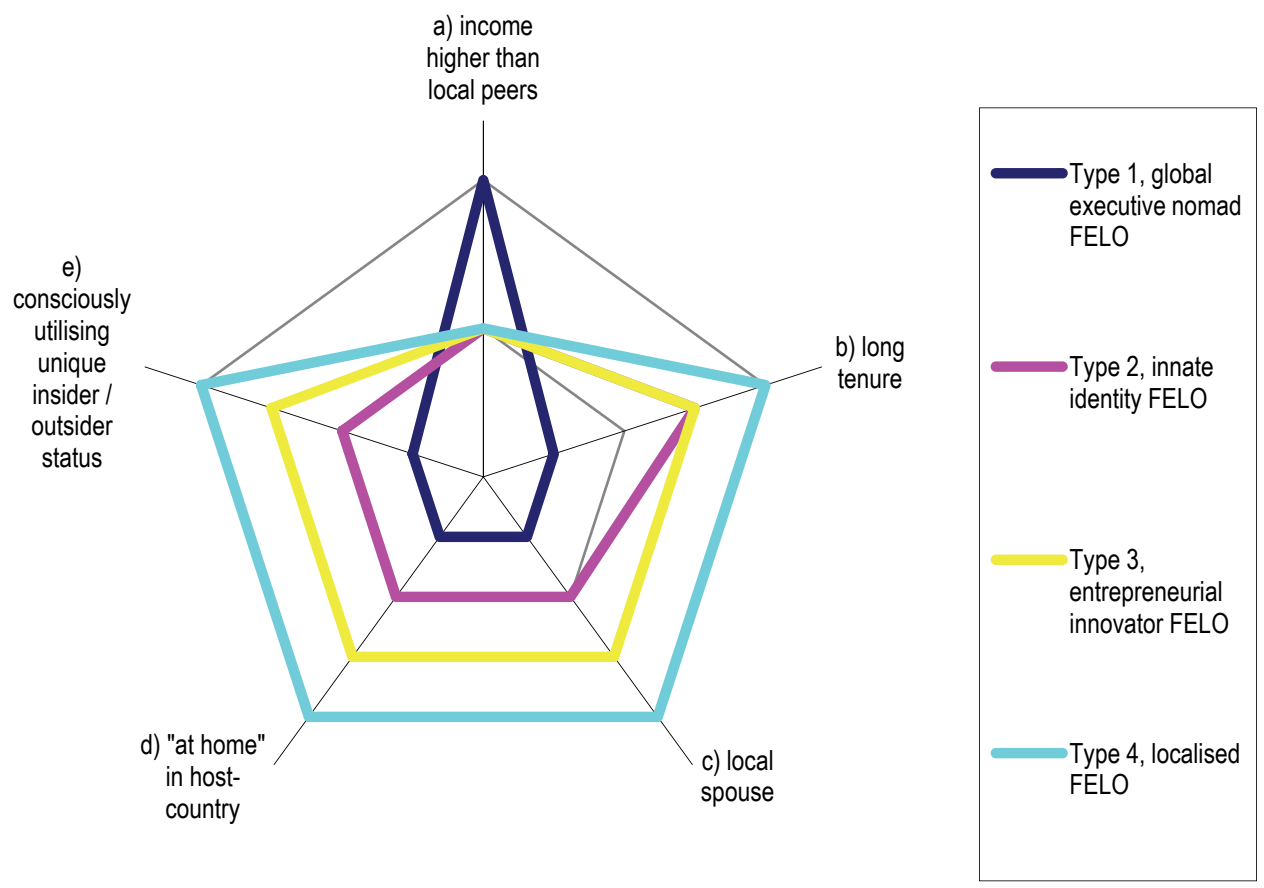
It represents in graphic form the commonalities as well as differences among FELO categories. For example, the likelihood of Type 1 FELOs having a higher income level than their local peers is greater than for Type 2, 3 and 4 FELOs. The ability to leverage their unique insider/outsider status is likely to be different for each type of FELO.

More nuanced distinctions between the four different types of FELOs are explicated in the following segments.

\section{Type 1: Global executive nomad FELOs}

These FELOs get appointed for specific expertise and hard skills, with a view to be replaced by local successors. Their (a) tenure in the local organisation is therefore limited from the outset. Frequently, younger Type 1 FELOs without previous work experience in the host-country are 'headhunted' by international executive search firms while some older ones have been expatriates in their host-country and prefer not to repatriate to their country-of-origin. These FELOs have (b) higher incomes than their local peers, sometimes on par with MNO-expatriates but often without the fringe benefits of the 'expatriate package' (e.g. housing and school fee allowances). If married, their (c) spouses typically come from the same country-of-origin and their social support network is usually limited to their foreign family and expatriates or other FELOs. Local colleagues primarily perceive these FELOs as outsiders (d) and the behavioural adaptation of these FELOs (e.g. linguistic variation to host-country norms) is deliberate, conscious, limited to a specific purpose, and to obtaining a desired outcome - to 'get something done'. The ability of Type 1 FELOs to develop, and make use of, their unique insider/outsider status (e) is limited.

Type 1 FELOs enjoy only a 'limited welcome', as local organisations would rather fill their positions with host-country nationals. FELOs are aware of this and 'sit on packed suitcases' (that is, they do not make a sustained effort to engage with local people and society). These FELOs mostly bridge foreign vs. host-country boundaries, rather than boundaries between host-country groups. Some Type 1 FELOs say: "I don't even have a bank account here" (FELO\#4) and "tomorrow home could be Beijing" (FELO\#13), and such comments were used to code low levels of involvement for label (d) 'at home' in the host-country. Local interviewees use the term 'expat' (rather than other descriptions) more frequently for this type than for the remaining FELOs. Type 1 FELOs are also the most visible in business media reports and appointments (as well as departures) may produce headlines.

It must be clearly understood that the difference between Type 1 and other types of FELOs does not lie in their income level, organisational and host-country tenure alone. Rather, the difference is due to the nature of their appointment. As these FELOs are aware of their limited welcome and the 'graduation ceremony' desired for their local successor, they are unlikely to contribute more than the expertise for which they are appointed. Psychologically, their situation does not allow Type 1 FELOs to integrate socially and develop significant levels of commitment to their host-country and employer. In a sense, this is the type of FELO produced by organisational and external constraints in many countries. The organisational focus on temporary engagements and succession plans as well as restrictive work permit procedures severely restricts the occurrence of all other types of FELOs. What local organisations obtain 
from Type 1 FELOs is (at best) the desired expertise for a period of time, but little else. Latent soft skills may be underutilised. In terms of diversity, some Type 1 FELOs probably may have a small developmental impact, in that one of their attitudinal or personality characteristics might happen to impress and inspire local colleagues. Other than this miniscule influence, akin to meeting any foreigner with a different perspective anywhere, host-country organisations and society do not gain much from such FELO workplaces. In sum, this type of FELO can be seen as part of a global competition for international executive expertise, and the primary distinction between them and traditional expatriates is the local employer. As one participant summarises:

They have been able to negotiate terms which are pretty much on par with expatriates. [..] And in fact that's what mostly they are: they are expatriates who are working for a local company rather than a foreign company. And many of them behave that way. But they are there because of expertise. (FELO\#8; coding nodes describe similarity to classic expatriates, indicate level of behavioural adaptation and causality of appointment)

\section{Type 2: Innate identity FELOs}

FELOs in this small category have innate characteristics that HCNs are - and will always be - unable to acquire. Type 2 FELOs are found in industries that require specific expertise inherent in, or generally associated with, a particular national, cultural or educational background. The objective is the replication of products or services available in other countries. The ability of these FELOs to 'portray and represent' their country-of-origin and the goods or services associated with it, or to speak a particular language and understand all its associated cultural nuances, combines with a need within local organisations to portray a foreign image or for high-level, nuancerich negotiation and interpretation of sensitive issues in a particular language. For example, a country's requirement to provide Islam-compliant versions of goods or services that are associated mostly with 'baram' (that is, forbidden by Islamic law) versions of that same product or service creates unique niches for FELOs who can straddle this particular divide:

I think the main criteria were that I spoke [language deleted] and $\boldsymbol{I}$ was there at that time. (FELO\#16; coding node indicates rarity and availability of innate characteristics inherent in linguistic, national and cultural background)

The selection is limited; there are not so many [details deleted] around. So the supply is limited. (FELO\#20; coding node indicates rarity; causality for appointment are innate characteristics inherent in national and cultural background)

The (a) tenure of Type 2 FELOs is limited to periods in which these innate characteristics are required in the local organisation, and their (b) incomes are reported to be in line with, or only slightly higher than, local peers. Lack of widespread demand for the specific identity or expertise narrows employment opportunities and gives local organisations a strong negotiation position. FELOs of this type have typically come to the host-country for coincidental reasons rather than on expatriate assignments. Local spouses (c) can be part of the coincidental reasons why these FELOs are in the hostcountry but do not explain FELO tenure, as Type 2 FELOs depend on their innate characteristics rather than host-country integration or cross-cultural skills. Hostcountry integration (d) is not a relevant element as Type 2 FELOs depend on their 'different-ness' rather than on integration. Type 2 FELOs with local spouses and at- 
tendant higher level of host-country integration are likely to develop the ability to leverage their unique insider/outsider status (e) in negotiations and relationships with local employers.

\section{Type 3: Entrepreneurial innovator FELOs}

These FELOs have typically come to their host-country on expatriate assignments or were appointed by local organisations on a project, consulting, or temporary contract basis. During that initial period, Type 3 FELOs have become closely involved with local business or social acquaintances, discovering new business opportunities. In contrast to Type 2 FELOs, such opportunities do not depend on innate expertise and the replication of products and services of other countries, but on the ability to translate a foreign concept into genuine innovation in the host-country context:

Within two or three years I took over, I had to put some money in. So, I had to risk it, I had to ... (FELO\#20; coding node describes entrepreneurial opportunity)

I think it was probably much easier here than in [my country-of-origin] [..]. And to make it successful is also much easier here than [in my country-of-origin]. (FELO\#24; coding node indicates opportunity and talent for innovation)

You know, they came originally for various reasons; some of them came through, erm, they were posted here by multinational companies, but then decided to stay on [..]. So, yeah, definitely there is a commitment, personal commitment, there's often a financial commitment because they, you know, invest in businesses and . . property ownership, family connections [..] I mean, they, they ... you know: they care about Malaysia [..] they feel part of the, erm, you know the social fabric of the nation. So, definitely there's a huge difference between them and the typical expat that comes to Malaysia. (LOCAL\#16; coding nodes indicate differences to other types of FELOs, describe levels and forms of host-country involvement as well as entrepreneurial innovation)

Their (a) long tenure and host-country experience causes Type 3 FELOs to unconsciously adapt cross-culturally in their private lives. Type 3 FELOs often are - or are treated as - partners, shareholders or co-owners in the organisations for which they work. In conglomerates, they are typically CEO of the division they co-founded. Accordingly, their (b) income level is typically on par with their local peers and dependent on the organisation's business success. That includes cases where FELO incomes are lower than that of local executives in comparable organisations. Frequently, local spouses (c) are part of the reason why these FELOs choose to live and work in their host-country; they typically were instrumental in these FELOs' ability to understand the host-country context, discover entrepreneurial opportunities, and deal with external constraints. Often, but not necessarily, local spouses or their families are associated with the entrepreneurial business venture. Type 3 FELOs may not have become 'entrepreneurial innovators' in their country-of-origin; interview comments suggest that host-country exposure, the opportunity to be different, and to do things differently, triggers this innovative ability. Their ability to innovate is based on a thorough understanding of, and integration with, the host-country environment (d). At work, their innovator role often requires them to consciously and deliberately behave in an un-adapted manner, and to make use of their (e) unique insider/outsider status. 


\section{Type 4: Localised FELOs}

These FELOs have typically moved from an initial expatriate assignment through several positions with local organisations, often with advisory or consulting roles as intermediate steps. Periods as Type 1, 2 and/or 3 FELOs may be part of their career history. In addition, Type 4 FELOs are frequently involved with host-country industry associations, local societies and charities. Their expertise primarily consists of an outsider's perspective on international business, combined with an insider's understanding of the local environment, soft skills predominantly acquired and honed locally, and the ability to bridge national boundaries as well as those between host-country groups.

Type 4 FELOs have (a) very long host-country experience and tenure in local organisations, and are different from migrants or permanent residents primarily due to restrictive immigration regulations and practices of their host-country. Southeast Asian countries very rarely grant permanent residence or dual citizenship and in the case of Malaysia, these restrictions have been acknowledged in a recent report: "The government and private sector must work together to improve the conditions that are driving Malaysian and expatriate talent to locate abroad." [..] "There needs to be a build-up of a critical mass of skilled professionals through simpler work permit and immigration procedures", and "a key consideration [..] is the offer of permanent residence to these" (NEAC, 2010, p. 125). Type 4 FELOs have frequently accepted (b) lower levels of income than in their country-of-origin, other countries, or as expatriates in subsidiaries of foreign multinationals. Their income levels have typically moved through several stages from expatriate assignment level, via quasi-expatriate pay on a consulting or contract-basis, probably through periods with less income than local peers, to ultimately be in line with their local executive peers. Type 4 FELOs are well integrated with local society through (c) local marriages, family and friendship ties. However, these social ties are not necessarily the causal element for their continued presence in the host-country. Instead, social ties including marriage and family appear to be the result and reflection of significant personal interest of these FELOs in their host-country and its people. Due to this (d) significant level of host-country integration, Type 4 FELOs are largely perceived by their peers to be part of their host-country society encapsulated by the frequently used term 'localised'. Foreign couples (that is, FELOs with life-partners who are not local) would not be perceived as 'localised', even after many years of host-country presence. Type 4 FELOs make use of their unique insider/outsider status in their private as well as their work life, and have developed a 'third-culture-ness' - a unique supranational stance on socio-economic issues combined with deep understanding of, and emotional involvement with, their host-country environment. Type 4 FELOs compensate their frustration, anxiety and anger about negative aspects of their host-country with high levels of idealistic commitment. As participants summarise:

The others are here to stay, you know, [..] — some of them are more Malaysian than Malaysians. Yeah, so there is a difference. (LOCAL\#12; coding nodes describe differences to other types of FELOs)

It's not myself; it's other people that I meet, they say: "Ah, you are local" [..] But I couldn't tell you what I've done to make them say it. (FELO\#10; coding node indicates difference to other types of FELOs)

Table 1 provides a side-by-side comparison of the different types of FELOs. 
Table 1: Typology of FELOs

\begin{tabular}{|c|c|c|c|c|}
\hline & $\begin{array}{c}\text { Type } 1 \\
\text { Global Executive } \\
\text { Nomad FELO }\end{array}$ & $\begin{array}{c}\text { Type } 2 \\
\text { Innate Identity FELO }\end{array}$ & $\begin{array}{c}\text { Type } 3 \\
\text { Entrepreneurial } \\
\text { Innovator FELO }\end{array}$ & $\begin{array}{c}\text { Type } 4 \\
\text { Localised FELO }\end{array}$ \\
\hline Causality & $\begin{array}{l}\text { FELOs' expertise ac- } \\
\text { quired abroad; needed } \\
\text { in host-country }\end{array}$ & $\begin{array}{l}\text { FELOs' innate charac- } \\
\text { teristics inherent in lin- } \\
\text { guistic, national or cul- } \\
\text { tural background }\end{array}$ & $\begin{array}{l}\text { FELOs' latent talent for } \\
\text { innovation finds nurture } \\
\text { and opportunity in the } \\
\text { host-country }\end{array}$ & $\begin{array}{l}\text { FELOs' soft skills and } \\
\text { commitment acquired in } \\
\text { the host-country; } \\
\text { coincidence }\end{array}$ \\
\hline $\begin{array}{l}\text { Aggregated typifying } \\
\text { comments from FELOs }\end{array}$ & $\begin{array}{c}\text { "I know my welcome } \\
\text { here is limited; once } \\
\text { they find a local with my } \\
\text { expertise / once l've } \\
\text { trained a successor, l'm } \\
\text { out" }\end{array}$ & $\begin{array}{l}\text { "A local simply cannot } \\
\text { do what I do because } \\
\text { they do not have my } \\
\text { unique background" }\end{array}$ & $\begin{array}{l}\text { "This country gives me } \\
\text { the opportunity to do } \\
\text { what I want to do, and to } \\
\text { be what I want to be" }\end{array}$ & $\begin{array}{l}\text { "I came here due to } \\
\text { happenstance; I will stay } \\
\text { here because I want to } \\
\text { contribute to this coun- } \\
\text { try; my life-partner is } \\
\text { here" }\end{array}$ \\
\hline $\begin{array}{l}\text { Aggregated typifying } \\
\text { comments from } \\
\text { LOCALs }\end{array}$ & $\begin{array}{l}\text { "This foreigner is an in- } \\
\text { ternationally recognized } \\
\text { expert in this field" }\end{array}$ & $\begin{array}{l}\text { "For this position, you } \\
\text { simply must have a for- } \\
\text { eigner of that nationality" }\end{array}$ & $\begin{array}{l}\text { "That foreigner made it } \\
\text { happen here" }\end{array}$ & $\begin{array}{c}\text { "That foreigner is com- } \\
\text { pletely 'localised' and } \\
\text { one of us" }\end{array}$ \\
\hline $\begin{array}{l}\text { Tenure in the local } \\
\text { organisation; } \\
\text { see characteristic (a) }\end{array}$ & short & $\begin{array}{c}\text { medium; on project con- } \\
\text { tract basis for some } \\
\text { Type } 2 \text { FELOs }\end{array}$ & medium & very long \\
\hline $\begin{array}{l}\text { Income level; } \\
\text { see characteristic (b) }\end{array}$ & higher than local peers & in line with local peers & $\begin{array}{l}\text { in line with, sometimes } \\
\text { lower than, local peers }\end{array}$ & in line with local peers \\
\hline $\begin{array}{l}\text { Remarks made to the } \\
\text { effect that 'this } \\
\text { country is home'; } \\
\text { see characteristic (d) }\end{array}$ & No & $\begin{array}{l}\text { Yes; conditional on de- } \\
\text { mand not changing } \\
\text { fundamentally for the } \\
\text { unmatchable skills or } \\
\text { identity }\end{array}$ & $\begin{array}{c}\text { Yes; but conditional on } \\
\text { business environment } \\
\text { not changing } \\
\text { fundamentally }\end{array}$ & $\begin{array}{l}\text { Yes; conditional, if at all, } \\
\text { on immigration rules and } \\
\text { socio-political } \\
\text { circumstances }\end{array}$ \\
\hline $\begin{array}{l}\text { Level of host-country } \\
\text { integration; also see } \\
\text { characteristic (d) }\end{array}$ & similar to expatriates & irrelevant & medium & high \\
\hline $\begin{array}{l}\text { Nature of behavioural } \\
\text { adaptation; } \\
\text { see characteristic (e) }\end{array}$ & $\begin{array}{l}\text { deliberate and con- } \\
\text { scious adaptation }\end{array}$ & unconscious adaptation & $\begin{array}{c}\text { privately = unconscious; } \\
\text { at work = conscious; } \\
\text { often deliberately } \\
\text { un-adapted }\end{array}$ & $\begin{array}{l}\text { unconscious; on occa- } \\
\text { sion deliberately } \\
\text { un-adapted; 'third- } \\
\text { cultureness' }\end{array}$ \\
\hline $\begin{array}{l}\text { Impact on host- } \\
\text { country }\end{array}$ & $\begin{array}{l}\text { Limited to 'knowledge } \\
\text { transfer' }\end{array}$ & $\begin{array}{l}\text { Very little; mere 'service } \\
\text { provider' role }\end{array}$ & $\begin{array}{l}\text { High economic impact; } \\
\text { limited societal impact }\end{array}$ & $\begin{array}{l}\text { High economic and so- } \\
\text { cietal impact }\end{array}$ \\
\hline $\begin{array}{l}\text { Local spouse; see } \\
\text { characteristic (c) }\end{array}$ & No & irrelevant & $\begin{array}{l}\text { Yes; sometimes affiliat- } \\
\text { ed with the business or } \\
\text { in the same organisation }\end{array}$ & $\begin{array}{l}\text { Yes; unlikely to ever be } \\
\text { considered 'localised' } \\
\text { without local spouse }\end{array}$ \\
\hline $\begin{array}{l}\text { Exposure to public } \\
\text { scrutiny }\end{array}$ & $\begin{array}{l}\text { High; appointment and } \\
\text { departure often subject } \\
\text { to controversy and } \\
\text { media interest }\end{array}$ & $\begin{array}{l}\text { Medium; due to innate- } \\
\text { ness / inherentness of } \\
\text { role }\end{array}$ & $\begin{array}{l}\text { Medium; uncontroversial } \\
\text { due to obvious } \\
\text { contribution }\end{array}$ & $\begin{array}{l}\text { Low; uncontroversial } \\
\text { due to long tenure and } \\
\text { 'working behind the } \\
\text { scenes' }\end{array}$ \\
\hline $\begin{array}{l}\text { Constraints on occur- } \\
\text { rence in host-country }\end{array}$ & $\begin{array}{l}\text { No; affiliation matches } \\
\text { immigration policy objec- } \\
\text { tives. Limited tenure typ- } \\
\text { ically causes (a) low } \\
\text { level of integration, and } \\
\text { (b) low effectiveness of } \\
\text { appointments } \\
\end{array}$ & $\begin{array}{c}\text { Yes; organisational and } \\
\text { external constraints } \\
\text { (immigration regulations) }\end{array}$ & $\begin{array}{l}\text { Yes; external (but not } \\
\text { organisational) con- } \\
\text { straints cause difficulties } \\
\text { (primarily a lack of } \\
\text { permanent residence } \\
\text { status) }\end{array}$ & $\begin{array}{l}\text { Yes; initial organisational } \\
\text { and persistent external } \\
\text { constraints including the } \\
\text { lack of permanent } \\
\text { residence status }\end{array}$ \\
\hline $\begin{array}{l}\text { Frequency in this } \\
\text { study }\end{array}$ & 13 & 3 & 17 & 13 \\
\hline
\end{tabular}

Frequencies result from quasi-Boolean operations on the coded data. Boolean operations employ logic operators such as AND, NAND (not and), OR and NOR (not or) to combine characteristics. With Boolean searches, constructed intersections of nodes can be created. Examples:

a) FELOs who say that 'this is home' AND that their social network primarily consists of their local spouse, family, and local friends AND that they feel estranged from their country-of-origin AND that they are 'not here for the money', AND where these comments are triangulated by comments from LOCALs

b) FELOs who say that they are appointed primarily for their specific knowledge and expertise NAND that they are 'not here for the money' NAND that 'this is home' AND where FELOs are referred to by LOCALS as e.g. 'local expat' rather than 'localised'

The Boolean operations can then be interpreted as a typology category, which for the two examples above would be (a) Type 4 Localised FELO, and (b) Type 1 Global executive nomad FELO respectively. 
Zeitschrift für Personalforschung, 27(3), 167-194

DOI 10.1688/1862-0000_ZfP_2013_03_Arp 183

German Journal of Research in Human Resource Management, 27(3)

\section{Typology of local organisations}

Various interviewee comments, mostly from LOCAL participants, distinguish between different types of local organisations, assess their relative likelihood of appointing FELOs, theorise about reasons for such appointments, and attempt predictions of the likely outcome:

I can't speak for others, but I think, for those Malaysian companies who are open to this type of concept \{i.e. FELOs\}, you can see them growing by leaps and bounds. There's a growth, as against the Malaysian 'Chinaman' companies who don't believe in expertise but believe only in themselves. I can see the distinct difference between the ways these companies will be able to grow. (LOCAL\#6; coding nodes indicate differences to other local organisations, provide descriptive details about the type of organisation and the mindset of their management teams)

Such comments are analysed for the typology detailed below. Key characteristics distinguished are the (a) form of ownership, control, and management, (b) size and type of organisation, and (c) motivation for FELO appointments, underlying hiring strategy and prevalent attitude to members of out-groups in these organisations. More comments are made about organisations least likely to appoint FELOs than comments that describe the specifics of organisations that do appoint FELOs. This may reflect the rarity of the FELO phenomenon and the survivorship bias in the study's sample. Participants probably find it easy to explain the exceptional nature of their own organisations through comments about the many other organisations that are less likely to appoint FELOs. Overall, the organisational typology broadly mirrors other forms of diversity (e.g. gender, ethnicity). As one interviewee explains:

If an organisation recognises the importance of diversity, then that often also translates to their openness to also hiring an expatriate [FELO]. Because if they're so reclusive and conservative - whether it's just male-dominated or Malay-dominated - then that openness is not quite there. (LOCAL\#19)

The typology described by participants also broadly matches the distribution of local organisations in this study's sample. Private enterprises form the clear majority of workplaces, while public-listed companies account for a third, and state-linked organisations constitute less than a tenth of FELO affiliations.

\section{Type A: Nationalistic, nepotistic, ethnocentric local organisations}

Type A organisations see little need for FELOs because "we have sufficient managerial talent ourselves" (LOCAL\#25; expressing ethnocentric sentiments). The presence of FELOs is attributed to hard skills and expertise only. Foreign executives are assumed to be motivated to work for local organisations only by financial rewards; their ability to contribute anything to local society beyond their expertise is questioned by representatives of such organisations.

First, single-ethnicity family-controlled-and-managed organisations as well as government-linked companies (GLCs) are seen as constituting this category. Top managers of such organisations are described as primarily locally educated, and exposed predominantly to local market and management perspectives. Decision-making processes are said to be hierarchical and appointments frequently based on nepotism rather than merit. 
Second, large GLCs may grudgingly admit temporary needs for specific innate knowledge at the subsidiary level provided by Type 2 FELOs, or even appoint Type 1 FELOs without these individuals becoming part of the inner corporate hierarchy. Large entities with the word 'National', ethnic, or country references as part of their corporate name are particularly unlikely to openly appoint FELOs for publicly visible positions, and some FELOs are given designations such as 'consultant' or 'advisor' instead.

Third, the prevalent stance toward members of out-groups in such organisations includes simmering resentment against 'Western' foreigners, and strong nationalistic and / or ethnocentric sentiments. Representatives of Type A organisations in the sample typically do not distinguish between expatriates, FELOs and foreigners in general. Comments underline that the FELO phenomenon is rare and will continue to be so for a long time.

A typical Malaysian company — whether it's family-owned or state-owned - I don't think they want that. They would bring him in as a consultant, but not necessarily as a senior executive. As a consultant because then it is not out in the open [..]. It's too 'in your face' to have a . . . a foreign executive. (LOCAL\#10; coding nodes provide description of TMT mindset prevalent in Type A organisations)

But, if we're just talking about a normal 'private limited' company, no. They won't bother bringing any in ... look at a 'Chinaman'-company, [their attitude is]: "I have my business; I have a 'private limited'. If my people can't do the job, I just get somebody else to do the job. I do not need to bring in any foreign expertise or executive!" (LOCAL\#23; coding nodes provide description of TMT mindset prevalent in Type A organisations)

\section{Type B: Pragmatic local organisations (but often short-term in orientation)}

The second category of local organisations is reported to see FELOs as a 'necessary evil' that is required to survive and grow in the market. Type B organisations are focused on the hard skill- and knowledge-based contributions of FELOs.

First, these organisations are owned by one or several closely-linked shareholders, but not managed exclusively by family-members appointed to their positions in nepotistic fashion. Some professional managers from ethnic groups other than that of the controlling family may hold senior positions with genuine decision-making power. $\mathrm{Di}$ versity at the professional management level includes gender, age, and ethnic variation.

Second, this category comprises medium-sized organisations and diversified conglomerates, frequently public-listed and exposed to foreign MNOs through competition or cooperation. In conglomerates, the appointment of FELOs is typically at subsidiary level, not on the board of the holding company. As one participant says:

It's an 'old boys'-network, ok? Who sits on the board has been on the board for the last twenty years, you know. And I don't think they would want somebody interfering with their judgement, you know. (LOCAL\#12)

Third, the prevalent attitude towards members of out-groups in these organisations takes the form of expectation and curiosity, mixed with trepidation about 'the unknown'. Foreign executives are seen as a way to leapfrog organisational development steps, and 'catch up with' foreign MNOs. Some local top executives are aware that this catching up involves learning from, and adopting, soft skills and attitudinal char- 
acteristics often thought of as 'foreign business culture'. The focus of these organisations is on temporary FELO appointments with the objective of mentoring a local successor.

You look at all Malaysian companies; probably $95 \%$ or more are all owner-managed businesses. And it's all family-type, tightly-controlled businesses. So, the example that I spoke to you about ... why they hire this American, this former CEO, is because that's not an owner-managed business. That is a public-listed company; and they need that expertise, that precise skill in that particular industry. (LOCAL\#9; coding nodes distinguish between Type A and Type B organisations)

\section{Type C: Local organisations with global mindset / local action}

A few local organisations are reported to appoint FELOs for reasons beyond hard skills, expertise and marketability. Although most local organisations are described as not very forward-looking, diversity-minded, or multi-culturalist, "there are exceptions, I think there are some companies that are much more forward-thinking but I think they are the exception" (FELO\#15; coding nodes distinguish Type C organisations from others).

First, Type $\mathrm{C}$ organisations are primarily found among organisations exposed to significant international competition, heavily involved in cross-border interactions, or in the process of becoming multinationals in their own right. Interestingly, some Type $\mathrm{C}$ organisations are active exclusively in the domestic market. Privately-held or stock market-listed, diversity of shareholder-ship is common, and decision-makers are typically well-educated executives exposed to international business, competition and management theory.

Second, Type C organisations range in size from very small niche-market players and 'born globals' to largish but strategically focused organisations. Very large organisations and conglomerates are less likely in this category, due to the socio-political sensitivity of FELO appointments.

Third, a welcoming attitude to diversity and to members of 'out groups' prevails in these organisations; outsiders, including foreigners, are seen as suppliers of new ideas, different perspectives and constructive criticism. LOCAL interviewees from Type $\mathrm{C}$ organisations had typically studied overseas, had extensive foreign experience, and see FELOs as very different from expatriates in the subsidiaries of foreign multinationals. Short comments include:

The forward-looking companies. . . in particular when they have experience with foreigners, tend to . . . they want to go forward with this $\{$ i.e. FELOs\}. Whereas for local Malaysian-domicile companies who do not deal much with foreigners, probably will not - because they have not seen the value in it. (LOCAL\#6; coding nodes distinguish Type $\mathrm{C}$ organisations from others)

I think the first thing that we are interested in employing these people [FELOs] is basically, erm . . . we are evolving the group, eventually, and hopefully towards the worldclass status. And, for what it's worth, Malaysia is still a developing country, say what you like. And the culture within an organisation is not very different from the culture within the country. (LOCAL\#6; coding nodes describe a Type B organisations on its way to becoming a Type $\mathrm{C}$ organisation) 
Based on such comments and coding nodes, a typology of local organisations is developed which is presented in Table 2 .

Table 2: Typology of local organisations

\begin{tabular}{|c|c|c|c|}
\hline & $\begin{array}{l}\text { Type A } \\
\text { Nationalistic, nepotistic, } \\
\text { ethnocentric }\end{array}$ & $\begin{array}{l}\text { Type B } \\
\text { Pragmatic (but often } \\
\text { short-termist) }\end{array}$ & $\begin{array}{c}\text { Type C } \\
\text { Global mindset / local action }\end{array}$ \\
\hline $\begin{array}{l}\text { Description in re- } \\
\text { gard to degree of } \\
\text { internationalisation } \\
\text { (DOI, cf. Sullivan, } \\
\text { 1994) }\end{array}$ & $\begin{array}{l}\text { Unwilling or unable to see any } \\
\text { need for FELOs; perceived as } \\
\text { 'national icon' or 'local local' } \\
\text { organisations by their man- } \\
\text { agement and staff as well as } \\
\text { outside observers (even if } \\
\text { very active in the international } \\
\text { market) }\end{array}$ & $\begin{array}{l}\text { Aware of the need for FELOs } \\
\text { due to their expertise and hard } \\
\text { skills; established or aspiring to } \\
\text { become multinational organisa- } \\
\text { tions (even if predominantly } \\
\text { active in the domestic market) }\end{array}$ & $\begin{array}{l}\text { Aware of the need for FELOs } \\
\text { due to their expertise, soft } \\
\text { skills, and contribution to di- } \\
\text { versity; perceived as 'interna- } \\
\text { tionalised' by their manage- } \\
\text { ment and staff (even when } \\
\text { active solely in the domestic } \\
\text { market) }\end{array}$ \\
\hline $\begin{array}{l}\text { Phase of organisa- } \\
\text { tional development }\end{array}$ & \multicolumn{3}{|c|}{$\begin{array}{l}\text { FELO appointments not contingent on market focus of local organisations. No clear distinction be- } \\
\text { tween a domestic, multi-domestic, multinational and global phase as in Adler \& Gundersen (2008). }\end{array}$} \\
\hline $\begin{array}{l}\text { Hiring strategy (cf. } \\
\text { Caligiuri \& Stroh, } \\
\text { 1995; Perlmutter, } \\
\text { 1969) }\end{array}$ & $\begin{array}{l}\text { ethnocentric } \\
\text { (but FELOs are a sign that key } \\
\text { headquarter positions cannot } \\
\text { always be filled with home- } \\
\text { country nationals) }\end{array}$ & $\begin{array}{c}\text { polycentric } \\
\text { (but FELOs are a sign that key } \\
\text { headquarter positions are some- } \\
\text { times better filled with foreign } \\
\text { nationals) }\end{array}$ & $\begin{array}{l}\text { geocentric } \\
\text { (and FELOs are a sign that } \\
\text { even key headquarter posi- } \\
\text { tions are sometimes best filled } \\
\text { with non-nationals) }\end{array}$ \\
\hline $\begin{array}{l}\text { Aggregated } \\
\text { typifying com- } \\
\text { ments }\end{array}$ & $\begin{array}{l}\text { 'We don't need foreigners to } \\
\text { tell us how to run our country; } \\
\text { when there's a specific skill } \\
\text { we need, we may temporarily } \\
\text { subcontract a foreigner as a } \\
\text { consultant' }\end{array}$ & $\begin{array}{c}\text { 'Foreigners are more advanced } \\
\text { in some fields; we want them to } \\
\text { bring their expertise here to men- } \\
\text { tor a successor; it also looks } \\
\text { good to have a FELO on the } \\
\text { board' }\end{array}$ & $\begin{array}{l}\text { 'We appreciate the different } \\
\text { perspective the FELO contrib- } \\
\text { utes; (s)he has brought for- } \\
\text { eign experience, learnt from } \\
\text { the local environment, and we } \\
\text { have learnt from her/him' }\end{array}$ \\
\hline $\begin{array}{l}\text { Most commonly } \\
\text { found among... }\end{array}$ & $\begin{array}{l}\text { Single ethnicity family con- } \\
\text { trolled and managed compa- } \\
\text { nies, government-linked or- } \\
\text { ganisations }\end{array}$ & $\begin{array}{l}\text { Medium sized professionally } \\
\text { managed companies, and sub- } \\
\text { sidiaries of larger conglomerates; } \\
\text { frequently public-listed }\end{array}$ & $\begin{array}{l}\text { Small to large organisations } \\
\text { very exposed to international } \\
\text { business ideas and manage- } \\
\text { ment style }\end{array}$ \\
\hline $\begin{array}{l}\text { 'Global Mindset’? } \\
\text { (cf. Kedia \& Muk- } \\
\text { herji, 1999, p 236; } \\
\text { Levy et al., 2007; } \\
\text { Tihanyi et al., 2000) }\end{array}$ & $\begin{array}{l}\text { TMT members do not normal- } \\
\text { ly have private contact with } \\
\text { foreigners; may have studied } \\
\text { abroad but often isolated from } \\
\text { host population }\end{array}$ & $\begin{array}{l}\text { TMT members travel frequently } \\
\text { and may have studied abroad. } \\
\text { Limited private contact to for- } \\
\text { eigners outside of work }\end{array}$ & $\begin{array}{l}\text { TMT members typically stud- } \\
\text { ied overseas, had extensive } \\
\text { foreign experience, see them- } \\
\text { selves as global citizens }\end{array}$ \\
\hline \multicolumn{4}{|c|}{$\begin{array}{l}\text { No frequencies are reported in this table, as this typology results from the analysis of comments about local organisations that } \\
\text { LOCAL and FELO participants work for presently, have worked for in the past, and other organisations referred to in anec- } \\
\text { dotes. Frequencies would therefore be misleading. }\end{array}$} \\
\hline
\end{tabular}

\section{Discussion}

\section{Typology of FELOs}

The findings of the present study illustrate that typologies of traditional expatriates (e.g. Black \& Gregersen, 1992) are not entirely relevant to the rare and specific FELO phenomenon. Categorisations such as 'dual allegiance' or 'hearts at home' are inapplicable as no type of FELO serves foreign headquarters. There are, however, similarities of Type 1 FELOs and the 'Hired Guns' in the Black and Gregersen (1992) typology, neither having much allegiance to the organisations for which they work. It must be 
noted, however, that this lack of allegiance is caused by the nature of Type 1 FELO appointments, and that those who take people management seriously may reject the 'gun-slinging' metaphor in the Black and Gregersen (1992) typology. A minority of Type 1 FELOs are similar to the sub-category of expatriates that Black \& Gregersen (1992) describe as 'plateaued-career free agents' - without opportunities in their home country and attracted to international assignments by attractive remuneration. In turn, Type 4 FELOs appear similar to 'gone natives' as described by Black and Gregersen (1992). However, Type 4 FELOs are proud of their long host-country experience and may find offensive the suggestion of having 'gone native' as this metaphor was used as a colonial era pejorative. It continues to have negative connotations.

Typologies that focus on the roles and tasks of expatriates (e.g. Hays, 1974) are useful to elucidate aspects of the FELO phenomenon as the selection and appointment of FELOs is similarly contingent on roles and tasks. For example, Type 2 FELOs (innately skilled unmatchable experts) are largely 'structure reproducers' that merely assist local organisations to replicate products, services or business processes that have originated in another country. In contrast, Type 3 FELOs genuinely innovate, although they generally operate at a lower level and despite their often entrepreneurial involvement, do not necessarily benefit much financially. The 'troubleshooter' and 'chief executive' roles (Hays, 1974) are usually reserved for Type 1 and Type 4 FELOs.

Overall, expatriate typologies with the most relevance to FELOs are those that take into account phases of psychological adjustment over time (Black \& Mendenhall, 1991; Shapiro et al., 2008). The 'localised' Type 4 FELOs with their significant hostcountry experience are able to contribute significantly more to local organisations than only the hard skills that they were appointed for initially (Arp, forthcoming 2013). Differences between FELOs with previous host-country experience and those without are similarly important, and the influence that previous experiential learning of FELOs has on knowledge transfer to, and capacity building in, local organisations is significant. In addition, local spouses have an important influence on how cultural distance is bridged (cf. Arp et al., 2011).

\section{Typology of local organisations}

Besides providing typologies of the under researched FELO phenomenon, a theoretical contribution of this research is a clarification and more refined understanding of the terms ethno-, poly- and geocentric. On first glance, FELO appointments in all three types of local organisation may be mistaken as indicators of a geocentric approach (i.e. recruiting and developing the best individuals regardless of their nationality and ethnicity for key positions everywhere in the world, including corporate headquarters). However, as the present research demonstrates, organisations that hire foreign executives for headquarter positions do not necessarily have a geocentric or nonethnocentric HRM approach. Indeed, the typical initial hiring reasons are far more mundane (cf. Arp, forthcoming 2013), and appointments do occur in organisations with strong ethnocentric HRM practices. Even those local organisations that hire FELOs primarily for expansion into international markets, for the portrayal of internationalisation (Type B organisations), or for the purpose of replicating products, ser- 
vices or business processes that have originated in another country (by appointing Type 2 FELOs) arguably follow a polycentric rather than a genuinely geocentric approach.

Another theoretical contribution, therefore, concerns the mindset of an organisation's top management team. Although this research has taken into account wellestablished categorisations in the literature, it illustrates that a 'global mindset' (Levy et al., 2007) and non-ethnocentric attitudes in the top management team are more important than ownership structure, size or industry for the success of FELO workplaces - just as they are for economic success (Caligiuri \& Stroh, 1995; Nummela et al., 2004). For example, the family-dominated and government-linked organisations common in Asia (see e.g. Claessens, Djankov, \& Lang, 1999; Claessens et al., 2000) are least likely to appoint FELOs although they might benefit most from any such appointments. Somewhat surprisingly, the data also indicates that FELO appointments are not contingent on the market focus and DOI of local organisations. Instead of a sequential progression of organisations from a domestic via multi-domestic and multinational phases to a global phase (as conceptualised in Adler \& Gundersen, 2008), a progression through mindset phases appears to matter most. Conceptually therefore, market focus, DOI and even the appointment of FELOs are result and reflection of this progression and FELOs are both objects and subjects, both clay and sculptor.

In addition, Caligiuri and Stroh's (1995) observation that non-ethnocentric management is possible only within the economic, social, political and legal constraints of the country of operation helps explain the rarity or absence of the FELO phenomenon in a number of countries. Work permit constraints limit the ability of local organisations to hire foreign talent, and FELOs with long host-country experience are unable to obtain permanent residence. It is this latter constraint which also distinguishes Type 4 FELOs from migrants: FELOs will always retain an out-group status in their host-country to a certain extent. Hence, it is insufficient to look at organisational typologies without considering the variations in welcome extended to FELOs by host-countries.

\section{Implications of the typologies presented}

Beyond comparing and contrasting the typologies resulting from this study to extant typologies of traditional and self-initiated expatriates, implications for practice need to be considered. The present study holds important implications for executive search consultants and TMTs of local organisations.

First, the findings suggest that foreign executives without significant host-country involvement are unsuitable for positions in local organisations. Some Type 1 FELOs are appointed through executive search consultants ("headhunters") without any previous host-country experience, and little commitment and loyalty to local interests. At the same time, Type 1 FELO appointments are typically made by organisations without genuine appreciation of national and cultural diversity in management teams (Types A and B in the organisational typology). Instead, appointments typically follow the short-term objective of catching up with international competitors while the candidate-organisation-context fit that can make FELO workplaces successful in the long term receives insufficient consideration. That focus on hard skills, marketability and 
credentials (cf. Arp, 2012; Arp, forthcoming 2013) is encapsulated in comments of research participants:

Many times I was called into a meeting, not because I was going to add any value to what was ongoing, except that I was a 'white face?. And it was sort of, like: "We're bonafide. We have us a white man". I was the token white man. (FELO\#13)

He had all the necessary ingredients to be successful. Why? Because the board was behind him, he joined at the right time, he had all the right credentials bla-bla-bla, experience and all that, right? There wasn't any reason why he should not do well. But guess what: he did fail. (LOCAL\#19)

As these relationships frequently do not last very long, bring high costs of search and employment, and can have damaging effects on organisational reputations through adverse international and local media coverage ("Nationalistic Asian company gets rid of foreign executive" / "Why did they appoint a foreign executive in the first place?"), they should be avoided. TMTs of Type A and B organisations exclusively focus on the specific expertise and credentials that they desire, but are unaware of the need for diversity of ideas, perspectives, cross-cultural experience and people management skills. Appointing Type 1 FELOs for short term change management interventions (and making them scapegoats, cf. Arp, forthcoming 2013) may be effective in a few exceptional cases, but more commonly required changes in organisational culture take time. In Type B organisations, having a foreign face in the TMT may be desirable for the portrayal of internationalisation. In those cases, the pragmatic but short-term focus on hard skills and marketability leads to FELO appointments in spite of rather than because of cultural distance. Genuine appreciation for the contribution of cultural diversity is lacking (or may only grow with time) and few executive search consultants seem to be prepared to advise local organisations appropriately. To an extent, this disregard for contextual factors is understandable. Credentials and hard skills are typically easy to document, quantify or measure as they are reflected in paper qualifications, degrees, or records of career accomplishment. Nevertheless, the typologies presented here may assist executive search consultants and their clients in their selection of suitable candidates. All FELOs described in a Korn/Ferry Institute (2009) publication, for example, appear to fall into the Type 1 category ('global executive nomad') of the present study. Although all FELOs are described as 'highly visible' in that publication, it is unlikely that current Type 2, 3 and 4 FELOs can be found through international executive search firms as many keep a low profile or work 'behind the scenes'. It is particularly unlikely that the most experienced Type 4 FELOs wish to be as highly visible as the more recent Type 1 FELOs appointed directly from abroad into Type A or B organisations typically are. Executive search firms should therefore scout for talent locally (that is, among long-term expatriates with significant host-country involvement) or among specific groups internationally (that is, among individuals who have been FELOs previously). Indeed, it may be a fruitful strategy for international executive search firms to develop databases of these two specific groups.

Second, in contrast to Type 1 FELOs, Type 3 and 4 often have very significant host-country involvement and appointments tend to last for many years. While Type 1 FELOs typically lack the cross-cultural skills to make use of their unique insider/outsider status, FELOs with significant host-country involvement (possibly includ- 
ing marriage to a local spouse) are able to leverage this status to the advantage of the organisation. The findings suggest that the most important contribution of FELOs is their role in long-term capacity building (Arp, forthcoming 2013). Their role as both external and internal bridge-builders, made possible by their unique insider/outsider status, does not come to bear during short-term appointments. While Type $\mathrm{C}$ organisations welcome the positive contribution that cultural distance, different perspectives, personal experiences, and broader horizons can make to their management team, Type A and B organisations are unlikely to consider these aspects among initial reasons for FELO appointments. If they would, they should consider candidates with significant host-country involvement and experience from previous FELO workplaces or expatriate assignments, and not living in 'expat ghettos'.

Third, Type 2 FELOs are likely to always have a place in international business and are a convenient choice for local organisations to replicate products or services available in other countries. However, Type 2 FELOs are quite aware that their presence is primarily due to their specific national or cultural background and not because of an appreciation of their hard or soft skills. Even without significant host-country involvement they may always find workplaces to 'portray and represent' their countryof-origin, assist in understanding nuances of a particular culture, or assist with nuancerich negotiations, but may never have the significant 'diversity of ideas and perspectives'-impact on local peers, colleagues and organisations that Type 3 and 4 FELOs can have.

\section{Limitations}

Among the limitations of typologies is their indicative nature. Typologies can never be absolutely definitive for all cases, nor are they sufficiently dynamic to capture all aspects of the FELO phenomenon. They do, however, provide an adequate framework to conceptualise the breadth of the FELO phenomenon, and help to identify which types of FELO workplaces produce successful outcomes and those that are likely to fail. Overlaps across categories exist, as well as progression of cases through typology categories over time. For example, a FELO with a local spouse is not automatically a Type 4 FELO. Similarly, an ethnocentric 'national icon' or a GLC may well be sufficiently non-political and free from partisan interference to appoint FELOs, and progress through less ethnocentric categories. Indeed, the perception that foreign executives may stand above sectarian preoccupations in their host-country can be the precise reason for appointments in such organisations. Further research should therefore include longitudinal case studies that can elucidate the progression through FELO workplace categories over time.

In addition, there are combinations from the organisational and individual typologies that are more frequent than others in the Malaysian study. These frequencies may be different in other economies, such as leading industrialised countries. Further, the cross-sectional nature of this study must be emphasised. The FELO sample of this study has a clear survivorship bias in that longitudinal data collected in any given country context may show a significantly larger cohort of current and previous Type 1 FELOs. In addition, the assessments of FELOs made by local research participants are likely a product of this survivorship bias towards Type 3 and 4 FELOs who in 
longitudinal studies are probably a much smaller cohort. The FELO phenomenon remains rare, after all, and longitudinal studies should be conducted, as mentioned above. Further research should also determine, probably through quantitative methods, the most frequent combinations in various countries — that is, through linkage of the above typologies, what types of FELOs are most commonly appointed by what type of local organisations and which of these combinations last.

A further limitation of the present study could be a lack of generalisability. Are the findings very specific to developing countries? Could FELOs and the types of organisations that appoint them be different in leading economies? Preliminary comparative work conducted on a small number of cases in Australia, China, Germany, Japan, Korea, Singapore and Vietnam suggests multiple similarities. For example, the reasons for Australian, German and Korean airline, engineering, finance, electronics and telecommunications companies to appoint foreign executives appear to be quite similar to the reasons for Malaysian, Chinese and Vietnamese companies to do the same. The reasons why some of these positions remain unfilled with local executives also appear to be similar, and the types of FELOs appointed appear to fall neatly into the typologies presented above. However, until systematic and rigorous research has been conducted in other countries, conclusions about generalisability (or a lack thereof) may be premature.

The purpose of this paper has been to advance clarification of the FELO phenomenon through typologies of the individuals and organisations involved. Despite frequently controversial media coverage, foreign executives and local organisations that appoint them remain under researched. Attention is drawn to findings that illustrate differences between FELO and other expatriate typologies. In detailing what types of foreign executives are appointed by local organisations and what types of organisations appoint them, this article contributes to the understanding of this remarkable cross-cultural management phenomenon.

\section{References}

Adler, N. J., \& Gundersen, A. (2008). International dimensions of organizational behavior (5th ed.). Mason, Ohio: Thomson South-Western.

Arp, F. (2012). For success in a cross-cultural environment, choose foreign executives wisely. Global Business and Organizational Excellence, 32(1), 40-50.

Arp, F. (forthcoming 2013). Emerging giants, aspiring multinationals and foreign executives: Leapfrogging, capability building, and competing with developed country multinationals. Accepted on 7 March 2013 for publication in an upcoming issue of Human Resource Management, Wiley, ISSN 0090-4848; abstract available at SSRN.

Arp, F., Hutchings, K., \& Smith, W. A. (2011). Different from expatriates: Foreign executives in local organisations. Refereed paper, accepted for and presented at the Academy of Management 2011 Annual Meeting, August 15, San Antonio Texas.

Arp, F., Hutchings, K., \& Smith, W. A. (forthcoming 2013). Foreign executives in local organisations: An exploration of differences to other types of expatriates. Accepted on 17 June 2013 for publication in an upcoming issue of Journal of Global Mobility, Emerald, ISSN 2049-8799; abstract available at SSRN.

Arthur, M. B., \& Rousseau, D. M. (1996). A career lexicon for the 21st century. Academy of Management Executive, 10(4), 28-39.

Bertrand, M., \& Schoar, A. (2006). The role of family in family firms. Journal of Economic Perspectives, 20(2), 73-96. 
Bird, A. (1994). Careers as repositories of knowledge: A new perspective on boundaryless careers. Journal of Organizational Behavior, 15(4), 325-344.

Björkman, I., \& Stahl, G. K. (2006). International human resource management research: An introduction to the field. In I. Björkman \& G. K. Stahl (Eds.), Handbook of research in international buman resource management (pp. 1-11). London: Edward Elgar.

Black, S. J., \& Gregersen, H. B. (1992). Serving two masters: Managing the dual allegiance of expatriate employees. Sloan Management Review, 33(4), 61-71.

Black, S. J., \& Mendenhall, M. E. (1991). The u-curve adjustment hypothesis revisited: A review and theoretical framework. Journal of International Business Studies, 22(2), 225-247.

Bozionelos, N. (2009). Expatriation outside the boundaries of the multinational corporation: A study with expatriate nurses in Saudi Arabia. Human Resource Management, 48(1), 111-134.

Caligiuri, P., \& Colakoglu, S. (2007). A strategic contingency approach to expatriate assignment management. Human Resource Management Journal, 17(4), 393-410.

Caligiuri, P., Lazarova, M., \& Zehetbauer, S. (2004). Top managers' national diversity and boundary spanning: Attitudinal indicators of a firm's internationalization. Journal of Management Development, 23(9), 848-859.

Caligiuri, P., \& Stroh, L. (1995). Multinational corporation management strategies and international human resource practices: Bringing IHRM to the bottom line. International Journal of Human Resource Management, 6(3), 494-507.

Carpenter, M. A., \& Fredrickson, J. W. (2001). Top management teams, global strategic posture, and the moderating role of uncertainty. Academy of Management Journal, 44(3), 533-545.

Claessens, S., Djankov, S., \& Lang, L. (1999). Who controls East Asian corporations? World Bank Research Observer, Working Paper ID. 2054(Working Paper ID. 2054),

Claessens, S., Djankov, S., \& Lang, L. H. P. (2000). The separation of ownership and control in East Asian corporations. Journal of Financial Economics, 58(1/2), 81-112.

Crabtree, B. F., \& Miller, W. L. (1999). Doing qualitative research (2nd ed.). Thousand Oaks, Calif.: Sage Publications.

Daily, C. M., Certo, S. T., \& Dalton, D. R. (2000). International experience in the executive suite: The path to prosperity? Strategic Management Journal, 21(4), 515-523.

Doherty, N., Richardson, J., \& Thorn, K. (2013). Self-initiated expatriation and self-initiated expatriates: Clarification of the research stream. Career Development International, 18(1), 97-112.

Dowling, P., Festing, M., \& Engle, A. D. (2008). International human resource management: Managing people in a multinational context. Cengage Learning.

Fraser, D. R., Zhang, H., \& Derashid, C. (2006). Capital structure and political patronage: The case of Malaysia. Journal of Banking \& Finance, 30(4), 1291-1308.

Froese, F. J. (2012). Motivation and adjustment of self-initiated expatriates: The case of expatriate academics in South Korea. International Journal of Human Resource Management, 23(6), 1095-1112.

GRTS. (2010). Global Relocation Trends 2010 Survey Report. New Jersey: Brookfield Global Relocation Services.

Hall, D. T. (1996). Protean careers of the 21st century. The Academy of Management Executive, 10(4), 8-16.

Harvey, M., Novicevic, M., \& Speier, C. (1999). The role of inpatriates in a globalization strategy and challenges associated with the inpatriation process. Human Resource Planning, 22(1), 38-50.

Harvey, M., Reiche, B. S., \& Moeller, M. (2011). Developing effective global relationships through staffing with inpatriate managers: The role of interpersonal trust. Journal of International Management, In Press, Corrected Proof.

Harzing, A.-W. (2001a). Of bears, bumble-bees, and spiders: The role of expatriates in controlling foreign subsidiaries. Journal of World Business, 36(4), 366-379.

Harzing, A.-W. (2001b). Who's in charge? An empirical study of executive staffing practices In foreign subsidiaries. Human Resource Management, 40(2), 139.

Harzing, A.-W., \& Ruysseveldt, J. v. (2004). International buman resource management (2nd ed.). London: Sage Publications. 
Zeitschrift für Personalforschung, 27(3), 167-194

German Journal of Research in Human Resource Management, 27(3)

Hays, R. D. (1974). Expatriate selection: insuring success and avoiding failure. Journal of International Business Studies, 5(1), 25-37.

Hymer, S. (1960). The international operations of national firms: A study of direct foreign investment. Cambridge, Massachusetts: Massachusetts Institute of Technology Press.

Inkson, K., Arthur, M. B., Pringle, J., \& Barry, S. (1997). Expatriate assignment versus overseas experience: Contrasting models of international human resource development. Journal of World Business, 32(4), 351-368.

Inkson, K., \& Myers, B. A. (2003). "The big OE": Self-directed travel and career development. Career Development International, 8(4), 170-181.

Kedia, B. L., \& Mukherji, A. (1999). Global managers: Developing a mindset for global competitiveness. Journal of World Business, 34(3), 230-251.

Lee, C. H. (2005). A study of underemployment among self-initiated expatriates. Journal of World Business, 40(2), 172-187.

Levy, O., Beechler, S., Taylor, S., \& Boyacigiller, N. A. (2007). What we talk about when we talk about 'global mindset': Managerial cognition in multinational corporations. Journal of International Business Studies, 38(2), 231-258.

Mendenhall, M. E., \& Oddou, G. (1988). The overseas assignment: A practical look. Business Horizons, 31(5), 78

Minichiello, V., Aroni, R., \& Hays, T. N. (2008). In-depth interviewing: Principles, techniques, analysis (3rd ed.). Sydney: Pearson Education Australia.

Mobley, W. H., \& Weldon, E. (2006). Advances in global leadership (Vol. 4). Oxford: Elsevier.

Myers, B., \& Pringle, J. K. (2005). Self-initiated foreign experience as accelerated development: Influences of gender. Journal of World Business, 40(4), 421-431.

Nachum, L. (2006). What constitutes the liablity of foreignness? Paper presented at the Academy of Management Proceedings, Atlanta, Georgia, August 2006.

NEAC. (2010). New economic model for Malaysia. Part 1: Strategic policy directions. Federal Government Administrative Centre, 62652 Putrajaya, Malaysia: National Economic Advisory Council.

Nowland, J. (2008). Are East Asian companies benefiting from Western board practices? Journal of Business Ethics, 79(1/2), 133-150.

Nummela, N., Saarenketo, S., \& Puumalainen, K. (2004). A global mindset: A prerequisite for successful internationalization? Canadian Journal of Administrative Sciences, 21(1), 51-64.

Palmer, T. M., \& Varner, I. I. (2007). A comparison of the international diversity on top management teams of multinational firms based in the United States, Europe, and Asia: Status and implications. Singapore Management Review, 29(1), 1-30.

Peltokorpi, V., \& Froese, F. J. (2009). Organizational expatriates and self-initiated expatriates: Who adjusts better to work and life in Japan? International Journal of Human Resource Management, 20(5), 1096-1112.

Perlmutter, H. V. (1969). The tortuous evolution of the multinational corporation. Columbia Journal of World Business, 4(1), 9-19.

Pudelko, M., \& Harzing, A.-W. (2007). Country-of-origin, localization, or dominance effect? An empirical investigation of HRM practices in foreign subsidiaries. Human Resource Management, 46(4), 535-559.

Richards, L. (2005). Handling qualitative data: A practical guide. London: Sage Publications.

Richardson, J., \& Mallon, M. (2005). Career interrupted? The case of the self-directed expatriate. Journal of World Business, 40(4), 409-420.

Searle, W., \& Ward, C. (1990). The prediction of psychological and sociocultural adjustment during crosscultural transitions. International Journal of Intercultural Relations, 14(4), 449-464.

Selmer, J., \& Lauring, J. (2010). Self-initiated academic expatriates: Inherent demographics and reasons to expatriate. European Management Review, 7(3), 169-179.

Selmer, J., \& Lauring, J. (2011). Marital status and work outcomes of self-initiated expatriates: Is there a moderating effect of gender? Cross Cultural Management, 18(2), 198-213. 
Selmer, J., \& Lauring, J. (2012). Reasons to expatriate and work outcomes of self-initiated expatriates. Personnel Review, 41(5), 665-684.

Shapiro, J. M., Ozanne, J. L., \& Saatcioglu, B. (2008). An interpretive examination of the development of cultural sensitivity in international business. Journal of International Business Studies, 39(1), 71-87.

Stahl, G. K., Chua, C. H., Caligiuri, P., Cerdin, J.-L., \& Taniguchi, M. (2009). Predictors of turnover Intentions in learning-driven and demand-driven international assignments: The role of repatriation concerns, satisfaction with company support, and perceived career advancement opportunities. Human Resource Management, 48(1), 89-109.

Stahl, G. K., Miller, E. L., \& Tung, R. L. (2002). Toward the boundaryless career: A closer look at the expatriate career concept and the perceived implications of an international assignment. Journal of World Business, 37(3), 216-227.

Staples, C. L. (2007). Board globalisation in the world's largest TNCs 1993-2005. Corporate Governance: An International Review, 15(2), 311-321.

Staples, C. L. (2008). Cross-border acquisitions and board globalization in the world's largest TNCs, 1995-2005. Sociological Quarterly, 49(1), 31-51.

Sullivan, D. (1994). Measuring the degree of internationalization of a firm. Journal of International Business Studies, 25(2), 325-342.

Suutari, V., \& Brewster, C. (2000). Making their own way: International experience through self-Initiated foreign assignments. Journal of World Business, 35(4), 417-436.

The Korn/Ferry Institute (2009). Lessons from the Asian C-suite: Building global talent and a culture for success. Retrieved 14 Aug, 2010, from http://www.kornferryinstitute.com/about us/thought leadership library/publication/1494/Lesso ns from the Asian C Suite

Tihanyi, L., Ellstrand, A. E., Daily, C. M., \& Dalton, D. R. (2000). Composition of the top management team and firm international diversification. Journal of Management, 26(6), 1157-1177.

Tung, R. L. (1981). Selection and training of personnel for overseas assignments. Columbia Journal of World Business, 16(1), 68.

Tung, R. L. (1998). A contingency framework of selection and training of expatriates revisited. Human Resource Management Review, 8(1), 23.

Vance, C. M. (2005). The personal quest for building global competence: A taxonomy of self-initiating career path strategies for gaining business experience abroad. Journal of World Business, 40(4), 374385.

Ward, C. (1996). Acculturation. In D. Landis \& R. Bhagat (Eds.), Handbook of intercultural training (2nd ed., pp. 124-147). Thousand Oaks, California: Sage Publications.

Ward, C., \& Kennedy, A. (1999). The measurement of sociocultural adaptation. International Journal of Intercultural Relations, 23(4), 659-677.

Weerawardena, J., Mort, G. S., Liesch, P. W., \& Knight, G. (2007). Conceptualizing accelerated internationalization in the born global firm: A dynamic capabilities perspective. Journal of World Business, 42(3), 294-306.

Zaheer, S. (2002). The liability of foreignness, redux: A commentary. Journal of International Management, $8(3), 351-358$. 
Order Form / all prices in EURO / all prices inclusive VAT*

\begin{tabular}{|l|c|c|c|}
\hline \multicolumn{1}{|c|}{ Order / Subscription } & & $\begin{array}{c}\text { Delivery charge } \\
\text { all countries } \\
\text { except Germany }\end{array}$ & \\
\hline $\begin{array}{l}\text { Zeitschrift f. Personalforschung 1-4/2013 } \\
\text { + IP or password access 2005-2011 }\end{array}$ & 80,00 & 13,80 & \\
\hline Zeitschrift f. Personalforschung 3/2013 & 24,80 & 3,45 & \\
\hline \multicolumn{2}{|r|}{ Total } & \\
\cline { 2 - 4 }
\end{tabular}

Within European Union: Payment after getting the invoice.

Payment per credit card: Please charge my / our credit account
[ ] American Express
[ ] Visa
[ ] Master Card

[ ]

Credit account no:

Credit card number:

Expiry date:

Name (as it appears on credit card):

Date + Signature:

Payment per cheque: Cheques should be made payable to Rainer Hampp Verlag and be drawn on a German bank.

FAX ++49 823330755 oder e-mail: Hampp@RHVerlag.de

\section{Rainer Hampp Verlag}

Marktplatz 5

$\underline{D}-86415$ Mering, Germany

(delivery address)

${ }^{\text {* }}$ For European companies: please add VAT: 